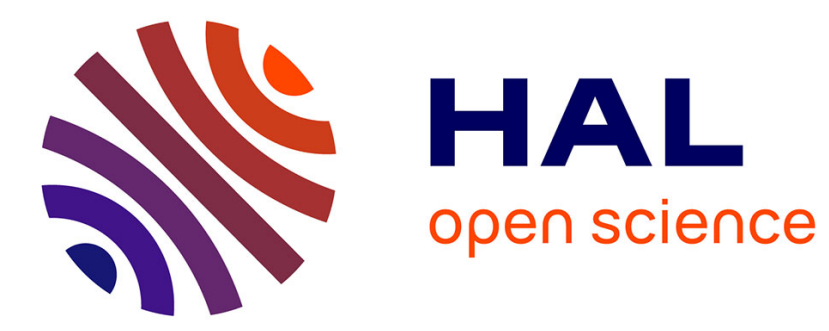

\title{
On interaction between external and internal markers in expressing aspect in Arabic dialect varieties.
}

\author{
Samia Naïm
}

\section{To cite this version:}

Samia Naïm. On interaction between external and internal markers in expressing aspect in Arabic dialect varieties.. Zlatka Guentcheva. Aspectuality and Temporality: Empirical and Theoretical Issues., 172, John Benjamins Publishing, pp.325-354, 2016, Studies in Language Companion Series, 9789027259370. 10.1075/slcs.172.10nai . halshs-01802634

\section{HAL Id: halshs-01802634 https://shs.hal.science/halshs-01802634}

Submitted on 5 Jun 2018

HAL is a multi-disciplinary open access archive for the deposit and dissemination of scientific research documents, whether they are published or not. The documents may come from teaching and research institutions in France or abroad, or from public or private research centers.
L'archive ouverte pluridisciplinaire HAL, est destinée au dépôt et à la diffusion de documents scientifiques de niveau recherche, publiés ou non, émanant des établissements d'enseignement et de recherche français ou étrangers, des laboratoires publics ou privés. 


\section{John Benjamins Publishing Company}

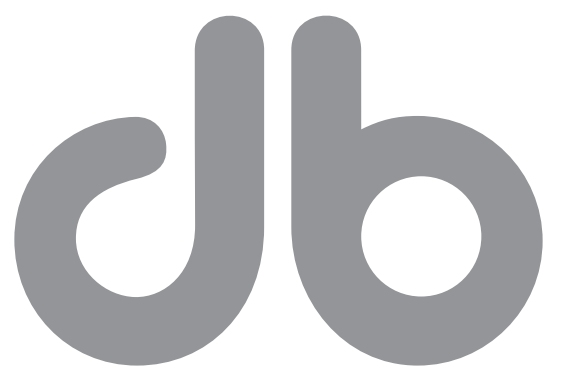

This is a contribution from Aspectuality and Temporality. Descriptive and theoretical issues. Edited by Zlatka Guentchéva.

(C) 2016. John Benjamins Publishing Company

This electronic file may not be altered in any way.

The author(s) of this article is/are permitted to use this PDF file to generate printed copies to be used by way of offprints, for their personal use only.

Permission is granted by the publishers to post this file on a closed server which is accessible to members (students and staff) only of the author's/s' institute, it is not permitted to post this PDF on the open internet.

For any other use of this material prior written permission should be obtained from the publishers or through the Copyright Clearance Center (for USA: www.copyright.com). Please contact rights@benjamins.nl or consult our website: www.benjamins.com Tables of Contents, abstracts and guidelines are available at www.benjamins.com 


\title{
On interaction between external and internal markers in expressing aspect in Arabic dialect varieties
}

\author{
Samia Naïm \\ LACITO-CNRS
}

\begin{abstract}
Themes, preverbs and particles partake in expressing aspectual notions. In this paper we will study the distribution of these markers and their grammatical and semantic compatibilities (when it is possible to retrace their etymology) with the two aspects inherent to the themes upon which the Arabic verbal system rests: the perfective and the imperfective. To what extent does the analysis of the affinities and incompatibilities between these external markers and the perfective and imperfective contribute to the definition of these very same notions? How to distinguish between constraints linked to verbal semantics (lexical aspect) and those which fall under one or the other of these two notions? This paper will also explore, from a crossdialectal and typological angle, which notions are encoded specifically and which belong to broader categories, so as to extrapolate the aspectual system dynamics in the dialects under study.
\end{abstract}

Keywords: Auxiliarity; affixation; grammaticalization; dynamic of aspectual systems in arabic dialects; syntax of basic aspectual notions; lexical semantics

Themes, particles and auxiliaries are all used in expressing aspectual notions. This study will look at their distribution and their grammatical and semantic compatibility with the two aspects which are inherent to the verbal bases of the Arabic verbal system, i.e. perfective and imperfective. To what extent does analyzing the affinities and incompatibilities between these external markers and the perfective and imperfective contribute to defining these same notions? How can one tease apart the constraints linked to verbal semantics (lexical aspect) and those linked to inherent aspect? We will also examine specifically encoded notions and those which are subsumed within broader notions, from both cross-dialect and typological perspectives, in order to shed 
light on the dynamics of aspectual systems in the eastern dialect varieties ${ }^{1}$ (Lebanon, Palestine) and in Yemeni varieties (Șan ${ }^{\complement} \bar{a}$, Zabīd). ${ }^{2}$

\section{The basic perfective imperfective distinction}

The two basic verbal paradigms in Classical Arabic and the dialect varieties are marked by suffixal and prefixal inflections, ${ }^{3}$ and are founded on an underlying perfective imperfective aspectual opposition. In speakers' minds this aspectual distinction is closely linked to temporal distinctions. In its absolute use, the suffixed inflection (perfective), termed al-mā $\bar{l} \bar{\imath}$ 'which is past, over', is automatically included in the sentence referential enunciative frame of reference and sets it in a past time frame. In contrast, the prefixed inflection (imperfective form), al-mudāri ${ }^{i} u$, is associated with a non-completed tense ("un temps non révolu"). ${ }^{4}$ Thus, in the absence of any specific context, the two basic forms of the verb $\left(\sqrt{z b}_{z}\right)$ 'joke' in the Șan'āni dialect are located by speakers in the past and in the general (non-referenced, generic) present: ${ }^{5}$ zabaz (PERF.3SGM) 'he joked' jizbiz (IMPERF.3SGM) 'he jokes'.

\subsection{Imperfective forms}

In a large number of dialects, changes in the verbal system have led to the inclusion of a referential marker in the verb form corresponding to one or both of the basic forms, the perfective and the imperfective. ${ }^{6}$ The Yemeni dialect of Zabìd has not undergone

1. Unless specified, examples are taken from my fieldwork corpus collected in Yemen, Lebanon, and Palestine. I have chosen to transcribe the examples taken from my corpus phonetically, so that dialectal variation be clearer for specialists of Arabic.

2. Henceforth (LEA) and (PEA) for the eastern dialects (EA) and (SYA) and (ZYA) for the Yemeni dialects.

3. Their traditional labels, which makes reference to where clitic pronouns are placed within the verb form. However, this label is not entirely accurate, as far as the "prefixal" inflection is concerned, because the person markers are discontinuous, and are both prefixed and suffixed.

4. It is moreover in these terms that the medieval grammarian Al-Zamaxfari defines the two verbal forms, in his treatise on Arabic grammar, ${ }^{3} u n m \bar{u} \partial a z$ fi al-naћw taking the time of speech for reference point: $A l-m \bar{a} d \bar{\imath} \imath$ "....refers to a process/event which took place in a time before yours...". Al-mudāri $i^{\mathrm{\Upsilon}} u$ "...which includes the present and the future... " (Kouloughli 2007: 133-142).

5. (Naïm 2009:67).

6. Cf. (Cohen 1989:187-89). 
such a change, i.e. it has retained the basic perfective imperfective distinction without any additional marker. In contrast, in the eastern sedentary dialects (EA), more specifically the urban varieties, and in the Yemeni dialect of Șan $\bar{a}$, changes in the verbal system have given rise to two imperfective forms, one bearing the prefix $b$ - and one "bare" form. The meanings of these two forms do not entirely overlap from one dialect to another, especially as concerns the marked form, where the meanings are system-dependent.

\subsubsection{The unmarked imperfective}

The unmarked form is found in both EA and sYA.

a) in dependent constructions:
(1) nizil
sa $s$ s sūq
jiftri
xadra
Descend.PERF.3SGM PREP the-souk buy.IMPERF.3SGM vegetables 'He went to the souk to buy vegetables.'
(2) daxal l-barik haggi-h jiytsil
enter.PERF.3SGM the-tub RP-3SGM wash.IMPERF.3SGM
'He entered his tub to wash.' (narrative context)
(3) tastiri thākì bi ș-șansānì?
knOW.IMPERF.2SGF speak.IMPERF.2sGF PREP the-șan'ānī
'(Is it that) you know how to speak șañānī (dialect)?'
(4) b-tasarfe tohke sarabe?
know.b-IMPERF.2sGF speak.IMPERF.2sGF Arabic
'Do you know how to speak Arabic?'

b) with modal values, in optative, jussive and exhortative constructions:

(5) jxalli- $k$ !

preserve.IMPERF.3SGM-2SGM

'(God) preserve you!'

(6) jirham wāldaj-k!

save.IMPERF.3SGM parents-2sGM

'(God), take pity on your parents!'

The two varieties, sYA and EA, differ in how they encode conditional clauses (7), descriptions of procedure (9), definitions and general truths (8). In these sentences, it is the "bare" imperfective which must be used in SYA, whereas in EA it is the prefixed imperfective (cf. 1.1.2).

(7) law tuxruzī la tuxruz kabid-ì la mūt (sya) if exit.IMPERF.2SGF then exit.IMPERF.3SGF liver-1sG then die.PERF1sG 'If you go, I will be deeply sad, I will die.' 
(8) allāh jißjī w jmìt

God give life.IMPERf.3SGM and make die.IMPERF.3sGm

'God gives life and takes (it) away'

(9) lamma tanðฺaz nəftah-ha

when be cooked.IMPERF.3SGF open.IMPERF.1PL-3SGF

naraffa-ha $\quad b^{\circ} \quad$ s-samn $w$ l-sasal

sprinkle.IMPERF.1PL-3SGF PREP the-fat and the-honey

'When it (the bread) is baked, one sprinkles it with fat and honey'

\subsubsection{The marked imperfective}

The imperfective bearing the prefix /b-/ has wider scope in the eastern varieties than in Șaña Yemeni Arabic since, as seen above, it is found in various types of declarative sentences, e.g. descriptions of procedure, definitions and general truths, as well as in the apodosis of hypothetical clauses introduced by ?in or 3iza, with the protasis introduced by either of the particles in the perfective (with exceptions) in the two dialect varieties.

$$
\begin{aligned}
& b \text {-tyīb } \quad \text { of-ams sa s-satte } \\
& \text { disappear.b-IMPERF.3SGF the-sun PREP the-six } \\
& \text { 'The sun sets at } 6 \text { o'clock.' }
\end{aligned}
$$

$$
\text { l-zansēn b-jæekul mitl }
$$

1-man b-eat.IMPERF.3sgm and b-die.IMPERF.3sgm like

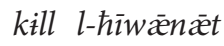

all the-animals

'Man eats and dies like all animals.' (Féghali 1928:22)

$$
\begin{aligned}
& \text { b-tralle l-ḅașle } w \text { l-laћme } w \text { basdēn } \\
& \text { fry.b-IMPERF.2sGF the-onion and the-meat and after } \\
& \text { b-tedelie l-majj } \quad w \quad{ }^{a} \text { r-razz } \\
& \text { pour.b-IMPERF.2SGF the-water and the-rice }
\end{aligned}
$$

'You fry the onion with the meat, then you pour the water and rice on top.'

$$
\begin{aligned}
& \text { riza fattit m-n?azzil. }{ }^{7} \quad l \text {-mifwār } \\
& \text { if raining.PERF3SGF delay.b-IMPERF.1PL the-walk }
\end{aligned}
$$

'If it is raining we can take the walk later.' (b-IMPERF $\mathrm{V}_{2}$ apodosis).

In contrast, in the Șan ânī dialect, the prefixed imperfective implies anchoring in a referential situation (14). Consequently, it can also denote a process concomitant

7. The /b-/ assimilates to the following nasal consonant: $\mathrm{b}-+\mathrm{n}>\mathrm{m}-+\mathrm{n}$ 
with the time of speech (15), or link a process to a related event, depending on the context (16).

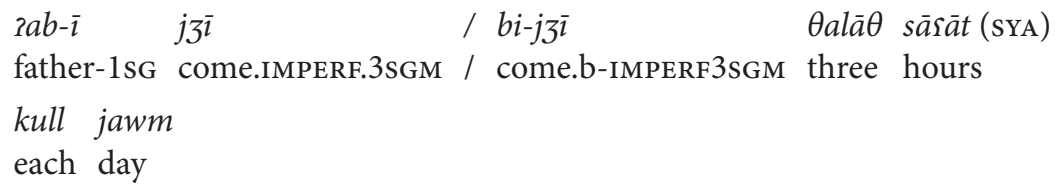

(16) $w$ basda hum fì d-dukkān b-jiftoylu l-safì and after them in the-store work.b-IMPERF.3PL the-evening daxal-ha sārig enter.PERF.3SGM-3SGF thief

'Then, while they were working in the store in the evening, a thief entered her house.' (The process rendered by 'enter' is secant to that of the subordinate clause).

In addition, contrary to what one finds in EA, in the Șan'ānī dialect, the marked imperfective is never found in the apodosis of conditional or hypothetical clauses: ${ }^{8}$

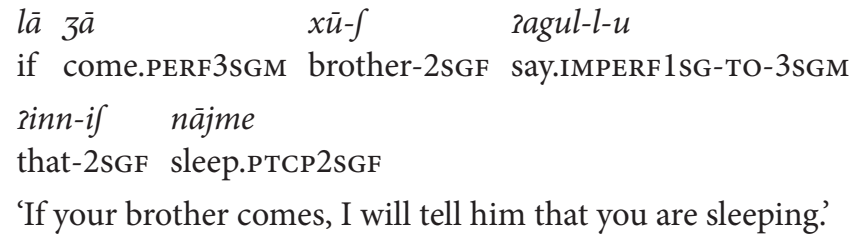

\subsubsection{Absence of the marked unmarked distinction}

The Zabid dialect, located in western Yemen, did not undergo reorganization and redistribution of the meanings of the imperfective into "bare" or absolute form $\sim$ prefixed form. In the absolute form, the imperfective is found in all contexts where it is found

8. On the relation realis $\sim$ potential in SYA, see (Naïm 2009:167-170). 
in EA and SYA (19-23) as well as in the contexts where EA and/or syA have recourse to the prefixed form (24-25).

ma $\int \bar{a} \quad \int \bar{\imath} \quad r a s m$ duxxān jabdì

NEG want.IMPERF.1SG INDEF name smoke appear.IMPERF.3sGM

'I do not want there to be any smoke whatsoever.'

tahni tfārḡì banī $k$ ?

(ZYA)

be able.IMPERF2SGF separate.IMPERF2sGF daughters-2sGF

'Can you leave your daughters?'

$\begin{array}{lll}\text { rata } & \text { l-malik jaxtab } & \text { ind- } u \\ \text { come.PERF3sGM } & \text { the-king ask the hand of.IMPERF.3sGM } & \text { at-3sGM }\end{array}$

'The king came to him to ask for the hand of (his) daughter.'

(22) mā tehabī?

INT dO.IMPERF3SGF

'What are you doing?' (right now)

(23) kalbit ramm-ì rabbās tanbuf-ik min furreh

bitch uncle-1sg Abbas bite.IMPERF3sGF-2sGF PREP bottom

(ZYA)

ma m-raș

PREP the-head

'(That) the bitch of my uncle Abbas bite you from your bottom to your head.'

$(24)$

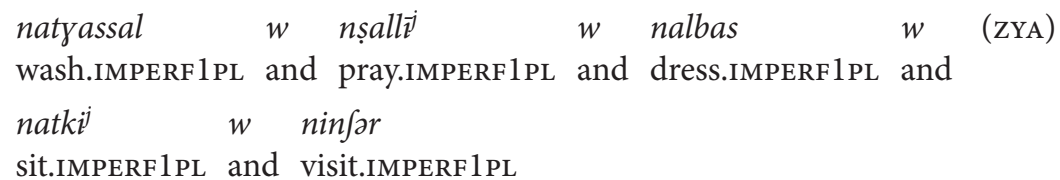

'We wash, we pray, we dress, we take qât and we visit each other.'
tyadde
/ $2 a r \int a \hbar$
/ tnarris

(ZYA)

lunch.IMPERF.1sG / sweat.IMPERF.1sg / be sleepy. IMPERF3SGF

'I am eating lunch'/'I am sweating.'/'She is sleepy'. (habitual or concomitant)

\subsection{The perfective}

In the three dialect varieties, the perfective has not split and has only one form. It is found in independent clauses, in subordinate clauses (with exceptions, e.g. subordinate clauses expressing a goal which are in the imperfective (26-28)) and in hypothetical clauses: counterfactual hypotheticals usually have a perfective in both protasis and apodosis $(29,30)$. In EA $(30)$, one notes the presence of the temporal marker kān 'be' (1.4) at the head of the apodosis, instead of the la particle found in SYA (29). 
(26)

nisidd az-zinīn sasibb natgāṣam-hin

(SYA)

count.IMPERF.1PL the-fabric SUB share.IMPERF.PL-3PL

'We count the fabrics to divide them up'

bākan tațlub thașsil-ha razq allah(ZYA) gO.PERF3SGF beg.IMPERF.3SGF obtain.IMPERF.3SGF-3SGF good God 'She went to beg, in the hope of help from God.'

stazzart sajjärah la zoțlas sa 3-3abal (LEA)
rent.PERF.1SG car PREP ascend.IMPERF.1SG PREP the-mountain 'I rented a car to go up the mountain.'

\begin{tabular}{|c|c|}
\hline $\begin{array}{l}\text { law } 3 \bar{i} t \bar{l} \\
\text { if come PERF2sG }\end{array}$ & lams $\frac{\text { la }}{\text { vesterdav }}$ \\
\hline$-l-i k$ & 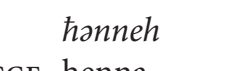 \\
\hline
\end{tabular}

'If you had come yesterday, I would have given you some henna.'

$$
\begin{array}{ll}
\text { law } \int \partial f t-\bar{i} & \text { kante } \\
\text { if see.PERF2SGF-3SGM } & \text { be.PERF.2SGF } \\
\text { dayre sraft-i } & \\
\text { right away } & \text { recognize.PERF2SGF-3SGM }
\end{array}
$$

[lit. if you saw him you were right away you recognized him] 'If you had seen him, you would have recognized him right away.'

The perfective is also found in performative sentences. These meanings result from interaction between the sentence's semantic and formal properties on the one hand, and discourse and pragmatic factors on the other hand. Verbs which produce this type of meaning, alongside verbs with performative scope (judicial sentences for example), ${ }^{9}$ mostly refer to the speech act itself: 'say, recount, tell, warn, prohibit.... They are used in daily conversation. ${ }^{10}$

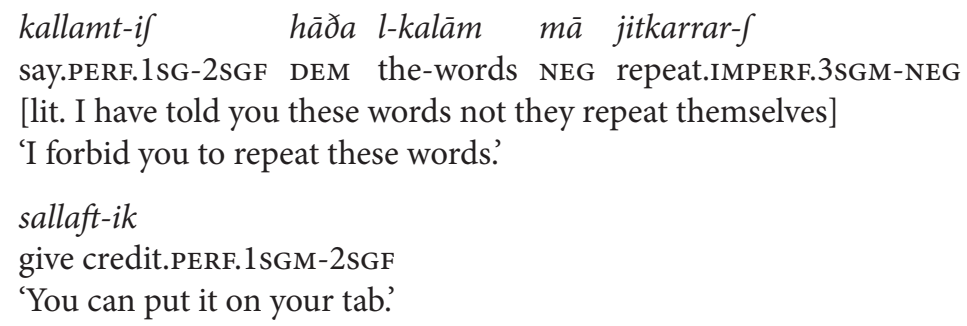

9. Verbs with performative scope partially overlap with those most usually found crosslinguistically, such as 'repudiate,' 'marry', 'swear', 'conclude a sale'... (Benveniste 1966; Austin 1970; Searle 1976; Récanati 1981).

10. (Naïm 1993). 
(33)

$\begin{array}{lll}\text { birt-ak } & b & \text { xamse } \\ \text { sell.PERF.1sG-2SGM } & \text { PREP five }\end{array}$

(ZYA)

'I'm selling (it) to you (it is a deal) for five.'

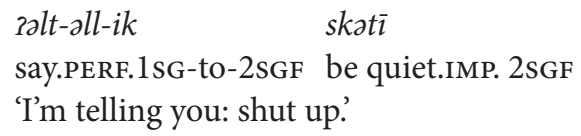

In all the above examples, the verb derives its illocutionary force from the use of the perfective in a specific syntactic, discursive and pragmatic context: I + v.PERF + you. ${ }^{11}$ However, with verbs with performative scope, i.e. those which belong to a ritual strongly anchored in social practices, one finds two types of constructions: containing a finite verb in SYA (35) and containing a participle in EA and SYA (35').
țallagt-if bi $\quad \theta-\theta a l \bar{a} \theta$
repudiate.PERF.1SG-2SGF PREP the three
'Three times, I declare you repudiated.'

(SYA)

?anti țāligah

2sGF repudiate.PTCP

'I declare you repudiated.' (= you are repudiated)

\subsection{Participial form}

Thus, in considering the basic forms of verbal aspect, one must take the participial form into account. It is used with a specific semantic category of verbs which can be either stative or dynamic, and which are often known as "middle verbs" (especially perception and experience verbs $(36,37)$, as well as movement and displacement verbs (38-40)). The participial form expresses a process which can be located in the present, past or immediate future, depending on the reference frame.

zantī dārje mà huw l-bint?

2sGF know.PTCP.SGF INT 3sGM the-girl

'Do you understand what 'girl' means?

(37) hì mkārfah masā-ha

3SGF argue.PTCP.SGF with-her

'She got into an argument with her.'

$$
\text { sājreh s-sūg }
$$

go.PTCP.1/2sGF the souk

'I/you am/are going to the souk'

11. The presence of the addressee is not obligatory linguistically marked. It is inherent to the situation of statement and can be expressed by a deixis or by a particular intonation, sent to the addressee or to the auditors (Naïm 1993:51-53) as in halaft or ragsamt "I swear". 
(39)

lana wārde la l-bēt
lsg return.PTCP.SGF PREP the-house
'I'm going back home.'

(40) fiān bājke?

INT go.PTCP.2SGF

'Where are you going?'

The participial form is used in the eastern and Yemeni dialect varieties. However, the list of verbs which may be used in this type of expression varies from dialect to dialect. Taking the verb 'be sleepy' for example, in zYA the verb is in the imperfective (25) whereas in SYA and EA it is in a participial form (41).

(41) mnassis

be sleepy.PTCP.3SGM

'He is sleepy'.

\subsection{Temporal anchoring}

As we saw above, the temporal dimension is never entirely absent from the aspectual system's two basic forms. Moreover, in their absolute use, the perfective and imperfective (as well as their participial forms) are localized by speakers in relation to the time of speech $\left(\mathrm{T}_{0}\right)$. The grammatical expression of linguistic verbal tense uses the auxiliary $k \bar{a} n$ 'be', placed to the left of the verbal core $\left(\mathrm{v}_{1}\right)$. The auxiliary $\left(\mathrm{v}_{2}\right)$ locates processes in relation to each other, or to any other reference point. It follows the $\mathrm{v}_{1}$ subject, gender and number agreement markers, and can be modified by a tense-aspect particle.

Depending on the desired temporal localization, $\mathrm{v}_{1}$ and $\mathrm{v}_{2}$ align on the same prefixed or suffixed inflection, or differ, PERF + IMPERF, IMPERF + PERF. To present these combinations, we have chosen sentences where both the main verb and the auxiliary are in their "bare" form, i.e. not associated with any collocational particle specifying mood, tense or aspect (with the exception of the indicative prefix b-IMPERF). In other words, the issue being addressed here is not how compound and multiple compound tenses are formed based on possible equivalents expressed e.g. by French passé antérieur, plus que parfait, futur antérieur, etc. ${ }^{12}$

\section{PERFECTIVE + PERFECTIVE}
kunt
sabbart
l-yada /
AUX.PERF.1sG prepare.PERF1sg the-lunch /
sabbart
l-yada
prepare.PERF.1sG the-lunch
'I had prepared lunch.' / 'I prepared lunch.'

12. Because the combinations between the meanings of the perfective and imperfective and various TAM particles also play a role in expressing compound and multiple compound tenses.

(C) 2016. John Benjamins Publishing Company

All rights reserved 
(43)
haddart
rada bas kènu
rakalu
prepare.PERF.1sG lunch but AUX.PERF3PL eat.PERF3PL

(LEA)

'I prepared lunch but they had eaten'.

PERFECTIVE + IMPERFECTIVE

(44) kān

dājman jaze

jzūrn-na

(LEA)

AUX.PERF/3SGM always come.PERF/3SGM visit.IMPERF/3SGM-1PL

'He always came to visit us.'

rams kunt fe?

yesterday AUX.PERF1SG want.IMPERF.1SG

'Yesterday I wanted to.'

$\begin{array}{ll}k æ \bar{x} \text { not } & \text { tabūk } \\ \text { AUX.PERF.3SGF } & \text { gO.IMPERF/3sGF }\end{array}$

'She was leaving/would leave (in the morning)'.

In the Zabìd dialect, when used as an auxiliary, kān has two perfective forms: the first form is regularly inflected, and the second form is only found frozen in the third person singular and bearing the nominal suffix (accusative or genitive marker) representing the subject of the modified verb. Because of its specific morphology (frozen form + nominal suffix) the fixed form, also much rarer than the regular form, is more akin to an aspect particle than to an auxiliary. I have only found it in a corpus of stories in the 2 nd person perfective (47).

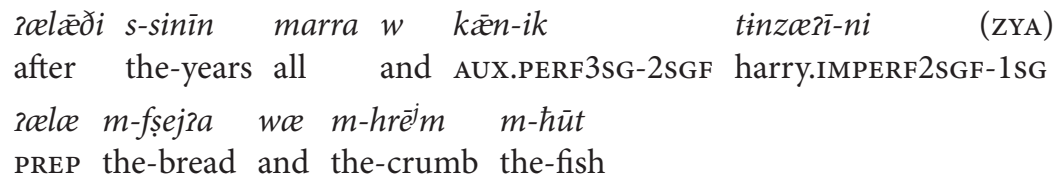

'After all these years, [(and) here you go/you come to] you harry me [again] with the bread and the bits of fish.'

This phenomenon is sufficiently specific to merit attention. ${ }^{13}$ According to Rossi (1938:250) it is (would have been?) attested in all Highlands dialects, including the Șan ${ }^{\Upsilon} \bar{a}$ dialect, but in his description of Șan ${ }^{\S} \bar{a}$ Arabic, it is only mentioned in a note in a collection of military songs (Rossi 1939:115). I have not personally encountered it in Șan'ā. In addition, in Rossi's corpus, $k \bar{a} n-a k(k \bar{a} n+2 \mathrm{SGM})$ is used as a copula in nominal sentences: kānak mugaddameh 'un tempo eri capo'. M. Cohen (1924: 125) shows the form $k \bar{a} n$ 'be' bearing a nominal suffix used as a copula in Mehri. In referring to this,

13. Because indeed it is not about the use of kann as a fixed or partially fixed particle as it is the case in other yemenite dialects (Behnstedt 1987:41; Watson 1993:154; Werbeck 2001:277-279). 
he uses the term "nominal conjugation". However, in the Mehri dialects today, it seems that this type of construction is not or no more in use. ${ }^{14}$

In the Zabīd dialect, it is not a nominal sentence because the augmented particle $k \bar{a} n-i k$ is followed by a verb in the imperfective (prefixed inflection). It is thus not easy to translate (47). In this context, should it be translated as 'you are still harrying me' with continuative/durative meaning, or instead as 'here you go' with ingressive meaning, as well as serving as a clause linker ${ }^{15}$ given the presence of the coordinator / w/ before kān [after all these years, you come and harry me?]? It is difficult to decide as the other examples attested in my corpus show little contextual variations. ${ }^{16}$

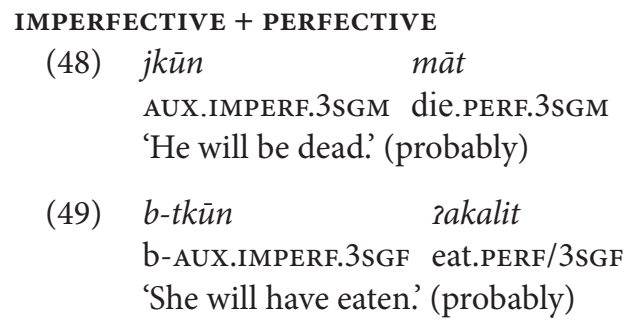

\section{IMPERFECTIVE + IMPERFECTIVE}

(50) rahjānan tikūn an-nugū $m \bar{a}$ tināsib-na (sYa) sometimes AUX.IMPERF/3PLF the-drawings NEG agree.IMPERF.3SGF-1PL 'Sometimes, the drawings do not suit us.' (possible)

$$
\begin{array}{lll}
b \text {-tūṣalu } & \text { bi-kūnu } & \text { sam-jēklu } \\
\text { b-arrive.IMPERF.3PL } & \text { b-AUx.3PL } & \text { eat.ram-IMPERF.3PL } \\
\text { '[When] you arrive, they will be eating.' (possible) }
\end{array}
$$

14. In the Mehri dialects spoken in Yemen and Oman, kān with suffixed inflection cannot be used as a copula (M.-C. Simeone-Senelle, personal communication; Watson 2012).

15. In the dialect of Șan $\bar{a}, k \bar{a} n$, frozen in the 3rd person singular, is used as a discourse marker (change or break of topic) and to denote temporal distance, which serves to encode the passing of time (Naïm 2009:79-80).

16. For example:

$$
\begin{aligned}
& \text { moejjot-ik } \quad w \text { doebbort-ik } \quad \text { w kǣn-ik } \\
& \text { kill.PERF1sG-2SGF and get rid of.PERF.1SG-2SGF and AUX.PERF3sG-2SGF }
\end{aligned}
$$

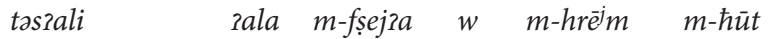

$$
\begin{aligned}
& \text { ask.IMPERF2SGF PREP the-bread and the-crumb the-fish } \\
& \text { 'I killed you, I got rid of you and here you go, you ask/you continue to ask for the } \\
& \text { bread and the bits of fish.' }
\end{aligned}
$$




\section{Comments}

- When the auxiliary is in the imperfective, modal meanings related to the context and semantics of $\mathrm{v}_{1}$ are grafted onto the temporal marking: the association $\mathrm{V}_{2}$ IMPERF $+\mathrm{V}_{1}$ PERF encodes what is probable; the $\mathrm{V}_{2}$ IMPERF $+\mathrm{V}_{1}$ IMPERF alignment expresses what is possible.

- With the volitional verb 'want', the association $\mathrm{V}_{2}$ PERF $+\mathrm{V}_{1}$ IMPERF in a discourse situation $(\mathrm{I}-\mathrm{you})$ is the equivalent of a conditional used for polite requests:
kunt
$2 a \int t \bar{\imath}$
?ari $-l-\bar{\imath}$
be.PERF/1SG want.IMPERF/1SG gO.IMPERF/1SG-DAT-1SG
'I would like (would have liked) to leave.'

\section{External markers: Auxiliaries and particles}

Auxiliaries and particles belong to two distinct grammatical categories. Auxiliaries show the same behavior as full verbs, i.e. they may be inflected in the two basic verbal conjugations, and can be modified by tense, mood and aspect particles ( $b$-, rah, $\int a / s a$ for the future, gad etc.). Some particles have verbal origins. They generally correspond to the 3rd person singular of the suffixal conjugation (perfective form), frozen and eroded, depending on the degree of grammaticalization in the various dialects.

Auxiliaries and particles express different aspectual meanings. Here they are grouped following their compatibility with the perfective and/or imperfective, as the perfective does not have its own particles nor preverbs. ${ }^{17}$ In this study, I have given precedence to the auxiliaries and particles, which contribute to the expression of the main aspectual notions, and for which I had a sufficiently large corpus to be able to vary the contexts.

\subsection{Auxiliaries}

Some aspectual auxiliaries stem from spatial expressions. These are mostly movement and displacement verbs, which have retained their regular use as "full" verbs. As auxiliaries, their syntactic scope is reduced to the modified verb (predicative core). Like the tense auxiliary kān (1.4), these auxiliaries agree in gender and number with the subject of the modified verb but do not necessarily bear the same (prefixed and suffixed) inflections. However, contrary to constructions with $k \bar{a} n$, when the auxiliary is in the imperfective, the modified verb cannot be in the perfective.

17. (Naïm 2009:80). 
The main aspectual notions encoded are the inchoative, ingressive, iterative and continuative. The lexeme (serving as auxiliary) modifying a given aspectual meaning can vary from dialect to dialect. Most often however, such variation is strictly lexical and has no bearing on the meaning conveyed.

\subsubsection{The inchoative}

By inchoative I mean the triggering of a process which will evolve. In this, it is distinct from the ingressive (2.1.2) which marks the suddenness of an event or entry into a state. The inchoative is mainly encoded by a posture verb, i.e. with no displacement, qasad/ resid, zalas/gilis (with cross-dialect phonological and lexical variation), equivalent to 'sit'.

Depending on the sentence's temporal setting, the auxiliary qasad (and its variants) is in the perfective (52-55, narrative) or imperfective (56, discourse), while the modified verb is always in the "bare" imperfective.

$$
\begin{aligned}
& \text { lammin rawwah el-walad sa d-dār w } \\
& \text { when leave.PERF3SG the-child DIR the-home and }
\end{aligned}
$$

'When the child went home and saw him dead, he started crying.'

(53) jesid jiћki rușas

AUX.PERF3SGM speak.IMPERF3SGM stories

'He started telling stories.'

gassu jabku

AUX.PERF3PL CrY.IMPERF3PL

'They started crying'

3alsit tadris

AUX.PERF.3SGF read.IMPERF3SGF

'She started reading the Koran.'
taglisi
tahdiri
inti $w$ jjāhe
AUX.IMPERF2SGF chat.IMPERF2SGF you and her
'[...] you start chatting with her.'

In jussive constructions, the auxiliary and modified verb are in the imperative mood:

$$
\begin{aligned}
& \text { gissi } \quad \text { sarrigi } \bar{\imath} \\
& \text { AUX.IMP2sGF light the candles.IMP2sGF } \\
& \text { '[...] start lighting the candles.' }
\end{aligned}
$$

Moreover, one notes other contextual meanings of the auxiliary which indicate a shift in meaning, from a movement-posture spatial meaning to an aspect-tense meaning denoting 'duration'. In $(58,59)$ zilis and resid (in the participial form) have come to mean 'stay, reside'. 
(58)

3ilis sindi-him jimkin risbūs

(SYA)

sit.PERF3SGM LOC-their perhaps week

'He stayed at their house perhaps a week.'
l-bajj
$b-j \int t y i l$
w l-ramm
iēsde
the-father work.b-IMPERF3sGm and
the-mother sit.PTCP.SGF
bi l-bajt
in the-home
[lit. the father he works and the mother sitting at home]
'The father works and the mother is a housewife.'

In various eastern dialects, the inchoative is also expressed by the auxiliaries ballaf 'begin' or șār 'become', followed by a modified verb in the "bare" imperfective. ${ }^{18}$
bas Jèfit
l-harāme ballajit
'When she saw the thief, she began to scream.'
rabki
sala $\hbar \bar{l} l-\bar{\imath}$
AUX.b-IMPERF1sG cry.IMPERF1sG over myself
'I began to cry over myself.'

tṣarrix

when see.PERF1sG the-thief AUX.IMPERF3SGF scream.IMPERF3SGF

(61) b-așìr
șāru
jqūlu
la l-malik
aUX.PERF3PL SAY.IMPERF3PL to the-king
'They began to tell the king.' 
2.1.2.1 qām, $2 \bar{a} m$ or gām 'get up'. Depending on the dialect, one finds qām, $2 \bar{a} m$ or $g \bar{a} m$ (phonological variants of the word initial consonant) to render the equivalent of 'get up'. As an auxiliary, the verb is found in the perfective and imperfective (with or without the prefix /b-/, depending on the dialect), the modified verb being in the imperfective or perfective, but the latter only if the auxiliary is also in the perfective. It is difficult to translate the ingressive, even though in most cases it has the same meanings as the adverb 'suddenly'. In the examples provided below, I have chosen to include an adverb in brackets within the translation, or as commentary between parentheses following the translation (66), depending on the context.

\begin{tabular}{|c|c|c|}
\hline$k \bar{a} n$ & sam-jiћki & $\operatorname{mas}-u$ \\
\hline EXT.PERF3SGM & sam-speak.IMPERF3sGM & with-him \\
\hline ?ām & dearab-u & \\
\hline
\end{tabular}

'He was talking to him, [suddenly] he hit him.'

$\begin{array}{llll}\text { kenna kel-na } & \text { wāqfinn } & \text { hadd el-srīs } & \text { b-iqūm } \\ \text { EXT1PL all-1PL } & \text { standing.PTCP near the-groom b-AUX3sGM } \\ \text { jeqSod } & \text { Ia 1-kerse } & & \\ \text { sit.IMPERF.3SGM } & \text { on the-chair } & & \end{array}$

'We were all standing beside the new bridegroom, and [suddenly] he sat on the chair.' (Féghali) ${ }^{21}$

$\begin{array}{lllll}\text { gad-i } & \text { maftazia la jgum } & \text { juloyga-ha } & \text { (sYa) } \\ \text { PART-3SGF } & \text { scared } & \text { that } & \text { AUX.IMPERF3SGM } & \text { strangle.IMPERF3SGM-3sGF }\end{array}$
'She was afraid he might [in one go] strangle her.'

lamma kabir qām xațab-l-o

when grow.PERF3SGM AUX.PERF3SGM betroth.PERF3SGM-DAT-3SGM

'When he was grown, he betrothed him' (without delay)

qāmu lisbu qämat ralabat-ih

AUX.PERF3PL play.PERF3PL AUX.PERF3SGF beat.PERF3SGF-3SGM

'They played, she beat him.'

Example (67) is composed of two juxtaposed clauses. The two successive events, 'play' and 'beat' are presented (from the narrator's perspective) as almost simultaneous, two parts to a single whole: the occurrence of the event 'beat' (perfective) partakes in the final phase of the event 'play' (perfective). To describe the ingressive more precisely, I will use the topological concepts open or closed boundary and interval (Desclés 1989;

21. In the examples taken from Féghali, I modified the transcription conventions and at times the translations provided by the author. For Féghali, example (64) is an "Inchoative" (1928:50). 
Culioli 1990). Thus one can represent (67) using a diagram where the closed final right boundaries of the two events coincide.

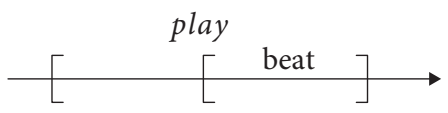

Diagram 1.

To describe things by order of their occurrence, one would simply remove the auxiliaries qāmu and qāmat from example (67) and replace them with two juxtaposed coordinated clauses. In (67'), the facts are presented in chronological order, 'beat' follows 'play'. In the diagram representing (67'), the right boundary of the event 'play' coincides with the left boundary of the beginning of the event 'beat':

$$
\begin{aligned}
& \text { lisbu w yalabat-ih } \\
& \text { play.PERF3PL and beat.PERF3sGF-3sGM } \\
& \text { 'They played and she beat him.' }
\end{aligned}
$$

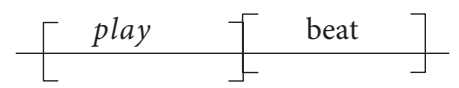

Diagram 2.

The notion of immediacy (imminence) or the lack of any clear delimitation between two events appears to be integrated in the notion of ingressive. It is present in the frozen and grammaticalized adverbial forms, such as q/rawām (EA), gijām (sYA) 'quickly, right away', and is strongly felt in the auxiliary's modal uses: in (68) gām preceded by the future particle / $\mathrm{a}$-/ expresses imminent future; in (69) the auxiliary and modified verb are in the imperative, and the auxiliary adds a meaning of imminence to the injunction. ${ }^{22}$

$$
\begin{array}{ll}
\int a-g u ̄ m & \text { Parah-l-i } \\
\text { PART/FUTURE-AUX.IMPERF1sG } & \text { leave.IMPERF1sG-DAT-1sGM } \\
\text { 'I'm leaving.' } &
\end{array}
$$

(69) $2 \bar{u} m$ $r \bar{u} \hbar$

AUX.IMP2SGM leave.IMP2SGM

'Leave (now)'

22. As an auxiliary, ?ām is also used to express other modal meanings such as the prohibitive and exhortative. It is also used as a narrative and discursive conjunction, in EA as well as in SYA and zYA with the meaning 'then, so' (Naïm 2009:87, and 2011). I will not further dwell on this subject, as it is beyond the scope of this paper. 
2.1.2.2 rāh 'go', $3 \bar{a}$ 'come'. The pair of verbs which encode the basic displacement notions 'go' and 'come' are used to express the ingressive in EA. Used this way, rāh is mostly found in Lebanese dialects (and Egyptian) ${ }^{23}$ whereas $3 \bar{a}(2 a z a, 2 a z a)$ is found in a greater number of eastern dialects.

In the Lebanese dialects, the choice of one or the other auxiliary rā or zaza depends on the nature of the modified verb:

- rāh is only found before finite verbs

(70) txēnaiu sawa rāhit

argue.PERF1PL together AUX.PERF3SGF

battalit tilsab

renounce.PERF3SGF play.IMPERF.3SGF

'They got into an argument, he stopped playing.' (immediately)

- 2əza is compatible with finite verbs and participial forms. Before a finite verb, zəza expresses the sudden advent of an event (71), illustrated in diagram 3.

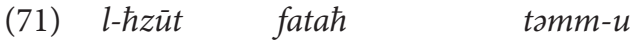

the-dragon open.PERF.3sgm mouth-3sGM

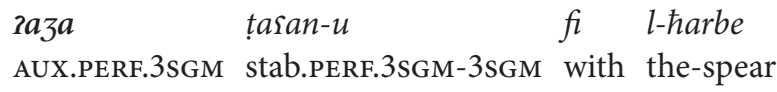

'The dragon opened its mouth, [all of a sudden] he ran it through with his spear.'

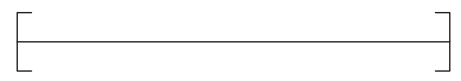

Diagram 3.

Preceding a participial form, $23 z a$ emphasizes the result or the consequences of the occurrence, i.e. it indicates entry into a state $(72,73)$ as illustrated in diagram 4.
darab-u
kaff raza
mlarrah
sa l-zard
hit.PERF3sGm slap AUX.3sgm lay out.PTCP3SGM on the-ground

(LEA)

'He slapped him, [there he was] flat out on the ground.'

(73)

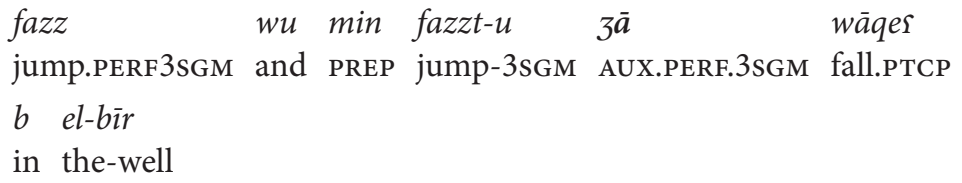

'He jumped [there he went] fell in the well.' (Féghali) ${ }^{24}$

23. Cf. Woidich (2006:331).

24. The translation I propose for this example is not that of Féghali, who translates it as 'He jumped so high that he fell in the well' (1928:104). It is true that the prepositional phrase

(C) 2016. John Benjamins Publishing Company

All rights reserved 


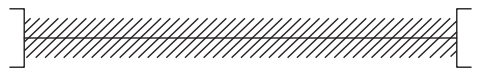

Diagram 4.

In (70-71) one could replace rähit and $2 a z a$ by the auxiliary $2 \bar{a} m$ (2.1.2.1) but this is impossible in examples (72-73), i.e. with a modified verb in the participial form.

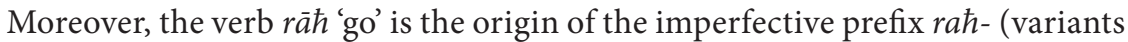
$r \bar{a} \hbar-$, la $\overline{-}$-), which is used in future conjugations in various dialects. ${ }^{25}$ Depending on the context, rah- + IMPERF conveys prospective (75), intentional (74) or imminent future meaning (76-77). The meaning of imminence, as we saw for the modal uses of the auxiliary get up (2.1.2.1), is included in the semantics of the aspectual ingressive.
$b i-n \int \bar{u} f$
lamma jṣìr
sane $\mathrm{fu}$ rah-tismal
year INT dO.PART-IMPERF2SGM

sumr-ak sifrīn

see.b-IMPERF1PL when become.IMPERF3SGM age-2SGM twenty

'We will see what you will do when you are twenty'.

(75)

zana rah-ziqtas l-majj san-kum

me cut.PART-IMPERF1SG the-water PREP-2PL

(PEA)

'Me, I'm going to cut your water off.'

(76) rah-t tatte

PART-rain.IMPERF3SGF

'It is going to rain/it will rain.'
rawwez
rah-jṣir
ad-dohr
hurry.IMP2SGM become.PART-IMPERF3SGM the-noon
'Hurry up it will soon be noon.' (Féghali, 52)

2.1.2.3 Inchoative and ingressive. In the literature, the inchoative and ingressive notions are at times considered synonymous. Thus in Bussmann's dictionary (1996), under inchoative:

'because of his jump' ( $\min f a z z t-u$ ) is not in my translation, but Féghali's ignores the ingressive meaning of the auxiliary $3 \bar{a}$ and of the participle 'fell'.

25. The particle used to express the future varies from dialect to dialect: in Șan $\mathbf{s}^{\S} \bar{a}$, one finds รa- ( $\{a$ - in the 1st p.), with two possible etymologies, $\varsigma a \overline{d a}$ 'come back' and $\hbar a t t a$ 'until', and in Zabìd one has $\int a$ - (conceivably from the modal $\int \bar{a} r a$ ' $\left.w a n t '\right)$. We will not explore here how the 'future' as such is expressed, nor the various modal meanings of the verb corresponding to 'go', which are beyond the scope of this paper.

(C) 2016. John Benjamins Publishing Company

All rights reserved 
Aspect of a verb or verb phrase. Inchoatives belong to the non-duratives (durative vs. non-durative) and indicate the inception or the coming into existence of a state or process [...]. Occasionally the term inchoative is also used synonymously for ingressive, which denotes the sudden beginning of an action [...].

In the dialect varieties under study here, those notions are clearly distinguished: qasad (and its lexical and phonological variants) 'sit' marks the inchoative (process), qām (and its phonological variants) 'get up' marks the ingressive (event).

The eastern dialects differ in that they have two other auxiliaries to mark the inchoative: ballaf 'begin' and șār 'become' depending on the semantics of the modified verb, and two other auxiliaries to mark the ingressive: rāh 'go' and $z \bar{a}$ 'come', depending on the viewpoint adopted by the speaker-narrator. However, the frontier between the inchoative and the ingressive can be very hazy: in (78) the auxiliary qām followed by the verb 'moan' does not express sudden entry into an action. In context, the three girls did not burst into tears (sudden event) but 'began to moan'; the auxiliary gilis 'sit' as in example (54) reproduced here as (79) works just as well.

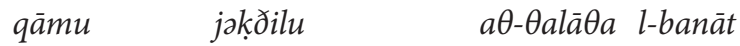

AUX.PERF3PL mOan.IMPERF.3PL the-three the-girls

'The three girls began moaning from the pain.'

(79)

gassu jabku

AUX.PERF3PL CrY.IMPERF3PL

'They began to cry.'

Therefore there are semantic contexts where the distinction between qaim (ingressive) gilis (inchoative) is neutralized because of the limited possible semantic combinations with the modified verbs (2.1.1).

\subsubsection{Continuative}

To express a process which has already begun or is ongoing, there are two auxiliaries in (EA): baqa (beqe, bere) and dall (ðall). The two verbs are synonymous. They have the meaning continue and either one may be used in the same context. The auxiliary is in the perfective or imperfective, and the modified verb in the "bare" imperfective or participial form, namely when it is a "middle" verb as in (83).

$$
\begin{aligned}
& \text { rabjoen figcera ọxelloen } \\
& \text { grow.PERF3SGF tree AUX.PERF3SGF }
\end{aligned}
$$

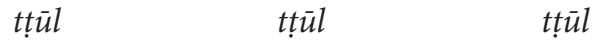

$$
\begin{aligned}
& \text { grow.IMPERF3SGF grow.IMPERF3SGF grow.IMPERF3SGF }
\end{aligned}
$$

'A tree grew, then continued growing, growing, growing.' 
(81) $\begin{array}{llll}\text { ha șabe beqe } & \text { jirḍas } & \text { ta șār } \\ \text { this the-boy } & \text { AUX.PERF3sGM } & \text { suckle.IMPERF3sGM } & \text { until become.3sGM }\end{array}$ somr-u sabs snin age-3sGm seven years

'This child continued to suckle until he was seven years old.' (Féghali) ${ }^{26}$
dallit
tabke
la ș-ṣobh
AUX.PERF3SGF cry.IMPERF.3sgF until the-morning
'She continued crying until morning.'
brīna
wērfīn
ta nkasar
dahr-na (LEA)
AUX.PERF1PL standing.PTCP1PL until break.PERF.3SGM back-1PL
'We remained standing until our backs were broken.'

\subsubsection{Iterative}

Iteration is expressed by two synonymous displacement verbs $s \bar{a} d$ and razî 'come back', and in sYa by a third auxiliary jzìd 'increase, multiply'. The displacement verbs did not evolve along the same lines in the eastern and Yemeni dialects, thus we will look at each in turn.

2.1.4.1 Razir/ragis 'come back'. In the eastern dialects and in sYA, the verb razis continues to function with its basic spatial meaning alongside its use as an auxiliary expressing iteration (84-86). As an auxiliary, it is never found in negative sentences (see under 2.1.4.2). Depending on the context, it can correspond to the prefix re('re-v') (87), to the adverb 'once again' (resumption of an interrupted action) or to the connectors 'then, after', namely when preceded by the coordinator /w/ 'and'.

$$
\text { raћna } \quad \text { rzasna }
$$

leave.PERF1PL and come back.PERF1PL

'We left and we came back.'

$$
\begin{array}{lllll}
\text { zasìr } & \text { așrof-oh } & w & a s i \bar{r} & l i \\
\text { go.IMPERF1SG } & \text { cash in.IMPERF1SG-3SG } & \text { and } & \text { go.IMPERF1sG } & \text { to }
\end{array}
$$
al-funduk [...] $w$ arzas the-hotel $[\ldots]$ then come back.IMPERF1sG

'I am going to cash it in then I am going to the hotel [...] then I will be coming back.'

$$
\begin{aligned}
& \text { bafüf-ak bas zarzas } \\
& \text { see.b-IMPERF1sG-2sGM when come back.IMPERF1sG } \\
& \text { 'I will see you upon my return.' (lit. when I come back) }
\end{aligned}
$$

26. Féghali translates beqe jirdas by a preterit 'this child suckled until...' which, in my view, does not convey the auxiliary's meaning (1928:75). 
(87)

rzast faft-u fit?

(LEA)

AUX.PERF2SGM SEe.PERF2SGM-3SGM INT

'Have you seen him again?'

rzis jgūl la ralli fi l-bistān

AUX.PERF3SGM Say.IMPERF3SGM to RLTV in the-garden

'Once again he said to the one who was in the garden.'

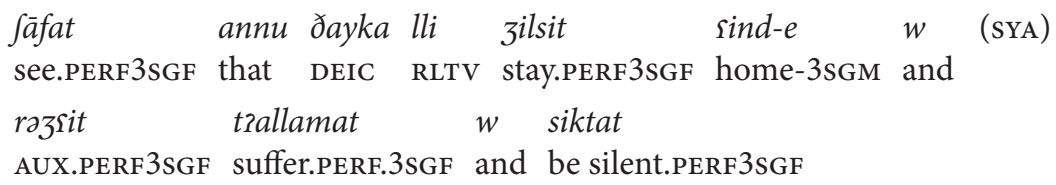

'She saw it was the man with whom she had stayed, so, once again, she felt hurt and remained silent.'

Depending on the context, dialogue or narration, the auxiliary can be in the perfective or imperfective (with or without prefix), and the modified verb in the perfective or "bare" imperfective. In (90), the auxiliary and the modified verb are in the imperfective, but only the auxiliary bears a prefix (b-IMPERF). However, e.g. in the eastern dialects, the modified verb can also be in the prefixed imperfective form. This can entail some ambiguity in interpreting the facts: the sentence in (90') for example can be interpreted in two ways, depending on the context and more particularly on intonation, whereas the sentence in (90) has only one interpretation, with dependence being strongly marked by the "bare" imperfective form.

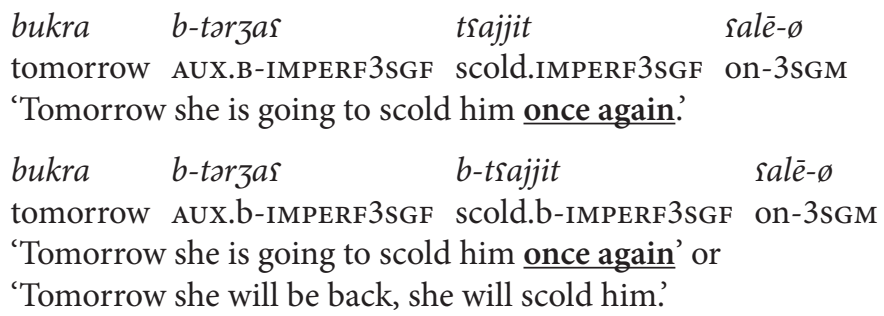

Tomorrow she will be back, she will scold him.

In the Zabìd dialect, contrary to what one finds in San ${ }^{\S} \bar{a}$, the verb ragi ${ }^{27}$ only serves as an auxiliary. In (91), the iteration applies to the verb 'go [beg]' (repetition of the same process). In (92), the two verbs 'shear' and 'stuff' are in the imperative, and the auxiliary serves as a clause linker, equivalent to the adverbs 'after, then'.

$$
\begin{aligned}
& \text { toebūk taṭlob }[\ldots] \quad w \quad \text { torge }^{2} \\
& \text { gO.IMPERF3SGF beg.IMPERF3SGF [...] and AUX.IMPERF3SGF } \\
& \text { toebuk le-he } \\
& \text { gO.IMPERF3SGF to-3SGF }
\end{aligned}
$$$$
\text { 'She went to beg [...] then she went [to beg], once again.' }
$$

27. In this dialect, it is the glottal stop $/ \mathrm{\gamma} /$ which corresponds to the pharyngeal fricative $/ \mathrm{s} /$.

(C) 2016. John Benjamins Publishing Company

All rights reserved 
(92)

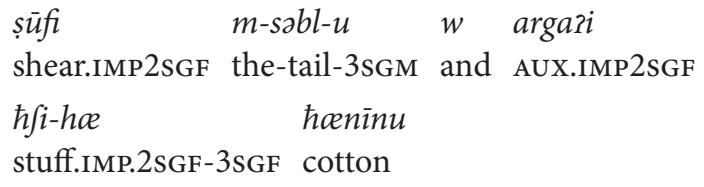

'You shear its tail and then you stuff it with cotton.'

2.1.4.2 sād 'come back'. Contrary to the verb razis, the verb sād (regional variant $\{\bar{a} w a d$ ) is not (no longer in EA) used as a 'full' verb. In EA, it serves as an aspectual auxiliary expressing iteration, like the verb razis, with which it can combine in negative clauses (95). In the eastern and Yemeni dialects, this verb is the origin of the tense-aspect and mood particle $\varsigma \bar{a} d(\mathrm{~s} a \mathrm{~d}, \mathrm{rad})$ which also serves as a copula in nominal predication (2.2.1). In the synchrony of the eastern dialects, $\varsigma \bar{a} d$ shows two degrees of grammaticalization: syntactic grammaticalization with a shift in meaning and reduction of the verb's scope (from full verb to auxiliary), and radical grammaticalization with a change in category (from verb to particle).

$\begin{array}{llll}\text { Rint ma wredt-ne } & f \bar{i}-h \quad \text { if } b-\bar{a} k \\ \text { you INT } & \text { promis.PERF.2sGM-1sG } & \text { in-3sG INT PREP-2sGM } \\ \text { sedt } & \text { yajjart } & f i k r-a k \\ \text { AUX.PERF2sGM change.PERF2sGM } & \text { opinion-2sGM }\end{array}$

'You had promised me, why have you once again changed your mind?' (Féghali)

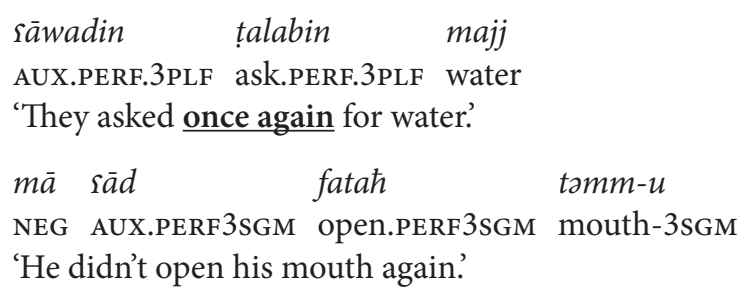

NEG AUX.PERF3SGM open.PERF3SGM mouth-3SGM

2.1.4.3 jzìd 'increase, multiply'. In the Șan'ānī dialect, the status of the iterative jzìd is ambiguous, between particle and auxiliary: like particles, it is frozen in the 3rd person singular but can have two forms, with one, $j z \bar{i} d$, preceding verbs in the imperfective (96), and the other, $z \bar{i} d$ (which also has a variant with a short vowel, zid), preceding verbs in the perfective (97). The form jzid corresponds to the 3 rd person of the prefixal conjugation, but the variant $z \bar{i} d$ can only be a shortened variant of $j z \bar{i} d$, which means that it does not correspond to the 3rd person of the suffixal conjugation. At the same time, jzid differs from particles in that it takes the feminine marker /t-/ (irregularly) when the subject of $V_{1}$ is of feminine gender (agreement in gender only) and can bear the imperfective prefix $b$ - (98) and the future particle $s a$ - ( $a$ in the 1st person) (99). 
(96) jiddow-l-ha

zanne jzìd jiddow-l-ha

zanne

give.IMPERF.3PL-DAT-3SGF dress AUX give.IMPERF.3PL-DAT-3SGF dress

'They give her a dress, they give her another dress [again].'

(97) gālu

hāða madrī rajn zid zāa

SAY.PERF.3PL this one NEG where AUX gO.PERF.3SGM

'They said: "This one, who knows where he is off to now [again]"'

madrī mā huwa llī bitzìd tuwarr-ī

NEG INT 3SGM RLTV b-AUX3SGF show. IMPERF.3SGF-3SGM

'I don't know what she's shown him this time [again].'

sa-tzīd tsawwī hākaða?

FUT-AUX.2SGF do.IMPERF.2sGF like this

'Are you (F) going to do the same thing [again]?'

One should also note that the shortened form zid combines with the negative particle $l \bar{a}$ to indicate that a event has ceased: lā zid xaraz 'He no longer went out'/'He never went out again..

\subsection{Particles}

We will examine two particles, $\varsigma \bar{a} d$ and gad, which convey at once aspectual, temporal and modal meanings. The particle gad is found in sya. The particle sād does not have the same status in all dialects.

\subsubsection{The particle sād- ( $\mathrm{rad}-$, ?ad-)}

In SYA, the particle $5 \bar{a} d-(2.1 .4 .2)$ is found before verbs in the imperfective (96) (or, as we shall see below, in the perfective (104)), and before participial forms (101). It is followed by a cataphoric pronoun (either suffixed or independent) representing the subject, except in negative sentences (103). Before verbs in the imperfective, participials, and in its copular uses (102), $\varsigma \bar{a} d$ denotes the continuation of an already ongoing process. Depending on the frame of reference, it can also denote concomitance (100).
(100) $\quad$ ād-u b-jiftarì
PART-3SGM buy.b-IMPERF3SGM
'He is in the process of buying.' (= he is still in the process of)
(101) sād-i zālisa fi bajt el-sazamij ðalhīn?
PART-3SGF sit.PTCP2sGF LOC home the-Ajami now
'Are she still living at the Ajami's?'
$\begin{array}{lll}\text { (102) } & s \bar{a} d-i & \text { marat-ak } \\ \text { PART-3sGF } & \text { wife-2sGM } \\ \text { 'Is she still your wife?' }\end{array}$

(C) 2016. John Benjamins Publishing Company

All rights reserved 


$$
\begin{aligned}
& m \bar{a} \text { sād albas hawla l-lada } \\
& \text { NEG PART wear.IMPERF.1sG these the-clothes } \\
& \text { 'I will no longer wear these clothes.' }
\end{aligned}
$$

Before verbs in the perfective (104), $\varsigma \bar{a} d$ serves to express quasi-contiguity between a prior perfective event and the speech event. ${ }^{28}$ Inversely, when $\varsigma \bar{a} d$ is followed by an imperfective bearing a "future" marker (prefix $s a-$ ), it is the event to be realized that is presented as imminent (105-106).

(104) sād-ani bsart-eh

PART-1SG See.PERF.1SG-3SG

'I just saw him.'

$$
\begin{aligned}
& \text { sād-u sa-jgor țabīb } \\
& \text { PART-3SGM become.ra-IMPERF3SGM doctor } \\
& \text { 'He is just about to become a doctor.' (imminent future) } \\
& \text { (106) sād-u sa-jhaddif } \\
& \text { PART-3SGM score a goal.Sa-IMPERF3SGM } \\
& \text { 'He is just about to score a goal.' (imminent future) }
\end{aligned}
$$

In the eastern and Yemeni dialects, $\varsigma \bar{a} d$ also serves as a discursive and narrative marker (especially after a pause), used to pick up the threads of a story after a shift in topic (in particular in Palestinian varieties). It differs from the verbal particle in that it is very seldom followed by a pronominal affix.

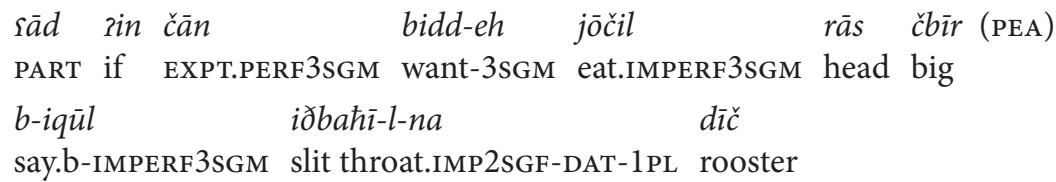

'So if he wants to eat a big head (of onion) he said behead a rooster for us.'

(108) sād fareqtên $\theta a l a ̄ \theta ~ \min$ hōn $\theta a l a ̄ \theta$ min hōn PART 2.teams three PREP here three PREP here

'So two teams, three over here, three over here.'

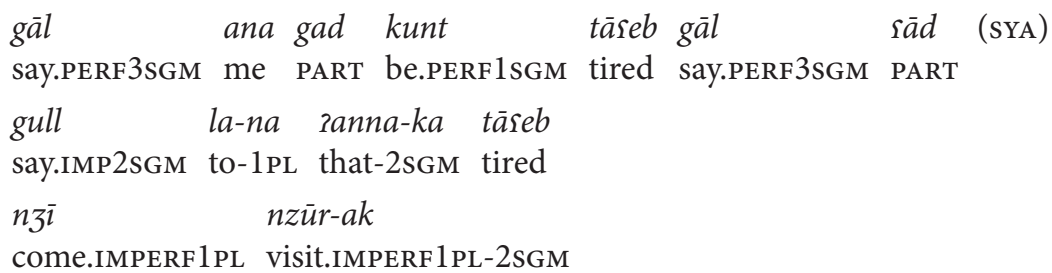

'He said: I was tired. He answered: but then you should have told us, so that we would visit you.'

28. On the manifestations of the notion of concomitance in verb forms (inherence adherence), see D. Cohen (1989:92-142).

(C) 2016. John Benjamins Publishing Company

All rights reserved 


\subsubsection{The particle qad (gad)}

The particle $g a d$ is found in sya only. ${ }^{29}$ As with $s \bar{a} d$, it is compatible with perfective, imperfective and participial forms. Contrary to $s \bar{a} d$ however, before a finite verb, it is usually not followed by an independent or suffixed subject pronoun, ${ }^{30}$ except for pragmatic reasons of subject emphasis: in example (110), the pronoun $/-\overline{1} /$, suffixed to $/ \mathrm{gad} /$, highlights the role of the wife in learning women's slang. ${ }^{31}$ In noun phrases however, the particle gad is regularly followed by a pronoun representing the subject (111). If the subject is lexically represented, it is never found between the particle and the predicate.

zillā llì hì marat-ih gad-ì tigul-l-ih except RLTV 3SGF wife-3sgm PART-3sgF say.IMPERF3sgF-to-3sgm

mas hù dārī mà bnithāka

NEG 3SGM know.PTCP CONJ speak.b-IMPERF1PL

'Except if it is his wife who is already teaching him, he does not understand what we are saying.'

(111) gad ana yaniy gawiy

PART 1SG rich a lot

'I am very rich.'

sas man gad-i gad-i kabìre rawla sād-i șīre (sYA) how INT PART-3SGF PART-3SGF big or PART-3SGF small 'What is she like? Is she [already] big or is she still little?'

Preceding a verb in the perfective, gad expresses assertive modal meaning by actualizing a truly completed event. In other words, it is a 'non-imperfective' form, to adopt a proposal by J.-P. Desclés. ${ }^{32}$

$\begin{array}{lllll}\text { gad } & \text { gulta-l-if } & m \bar{a} & \text { hij } & l \text {-zināze } \\ \text { PART } & \text { say.PERF1sG-to-2sGF } & \text { CONJ } & \text { 3sGF } & \text { the-burial }\end{array}$

'I already told you what [the word] jinaze (burial) means.'

(114) wa gad jiftī jasnī wlād jamanī mah?

and PART PERF.2sgF i.e. birth Yemeni no?

'You have already attended an end-of-lying-in ceremony in Yemen, haven't you?'

29. I.e. it is never found in the eastern varieties examined here nor in the Zabild dialect. It is found elsewhere in Yemen however, for example in the Yafi ${ }^{i}$ region (Vanhove 1996).

30. In the 2 nd p. one notes alternation between the tonic forms and the affixes, with both the particles $\varsigma \bar{a} d$ and gad, however the form affixed with $\bar{s} \bar{d}$ predominates: gad ant gad-ak, gad

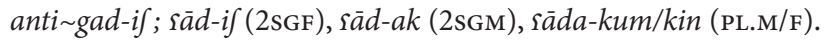

31. (Naïm 2009:197-200).

32. J.-P. Desclés p.c.

(C) 2016. John Benjamins Publishing Company

All rights reserved 
(115)
gad sabbart l-yada
PART prepare.1sG.PERF the-lunch
'I have already prepared lunch'.

(SYA)

In the following examples, gad serves to indicate that the marked process happened prior to another.

$$
\begin{aligned}
& \text { sārt 2umha makke thiz3 w } \\
& \text { go.PERF.3SGF mother3sgF Mecca pray.IMPERF.3SGF and }
\end{aligned}
$$$$
\text { rabū-ha gad màt }
$$$$
\text { father-3SGF PART die.PERF.3SGM }
$$

'Her mother had already been to Mecca to fulfill her duty and her father was already dead.'

$$
\begin{array}{lll}
\text { kamā gad ftayalt } & \int a-d d \bar{l}-l-i \int & \text { fulūs (sYA) } \\
\text { when PART } & \text { work.PERF.1sG } & \text { give.PART-IMPERF.1sG-DAT-2sGF money }
\end{array}
$$
'As soon as I have worked I will give you some money'.

(118) kama gad yini wāhad al-rensān ma sād when PART make rich.PERF.3SG IND the-man NEG PART jifgir- $\quad$ allah impoverish.IMPERF-NEG God

'When he [God] has made a man rich, God no longer impoverishes him.' $\begin{array}{llllll}\text { gālit } & \text { gad bnajt } & f \bar{l} & \text { nafs-i } & \text { min } & \hbar \bar{i} n \\ \text { say.PERF.3SG } & \text { PART decide.PERF.1SG } & \text { LOC } & \text { person-1sG of } & \text { when }\end{array}$ fuft-ak ann gad gult l-ah fa See.PERF.1SG-2SGM if PART Say.PERF.2SGM DAT-3SGM then hurimt salajj-i forbid.PERF.2SG PREP-1SG

'She said: As soon as I saw you I made the decision (I said to myself) that if you had already brought it back to him, I no longer would have been able to marry you.'

Before a verb in the imperfective (bare or preceded by the prefix /b-/), the particle gad conveys various modal meanings. Depending on the context, it can express assertiveness, as in $(120,121)$ :

$$
\begin{array}{lllll}
\text { linn gad gult-a } & \text { la-h } & m \bar{a} & \text { gad } \\
\text { if PART } & \text { say.PERF.2sg-3SGF to-3sGM } & \text { NEG } & \text { PART } \\
\text { 2abgā } & \text { sind-ak } & & \\
\text { stay.IMPERF.1sG-NEG } & \text { LOC-2sGM }
\end{array}
$$$$
\text { 'If you have told him, I will not stay at your place.' (you can be sure of it) }
$$ 
(121) al-wald hu tajjib w gad-u ðalћin

the-boy 3SGM good and PART-3SGM now

bi-șallì $\quad w$ xājif min alla

pray bi-IMPERF.3SGM and fear.PTCP PREP God

'This boy is good; now he prays and he fears God.'

When gad is followed by an imperfective preceded by the future marker (prefixes sa-/ $\mathrm{fa}-$ ), it anchors the sentence in quasi-certainty and encodes the imminent future. In such constructions, I find it difficult to determine the difference between the particle gad and the particle sād (2.2.1., 105-106).

$$
\begin{array}{lll}
\text { gad-u } & \text { sa-jgas } & \text { tabì } \\
\text { PART-3SGM } & \text { sa-fall.IMPERF.3SGM } & \text { doctor }
\end{array}
$$

'He will soon be a doctor.'

$$
\begin{array}{ll}
\text { gad } & \text { sa-jzannin } \\
\text { PART } & \text { Sa-IMPERF.3sGM }
\end{array}
$$

'He is just about to go crazy.'

$$
\begin{aligned}
& \text { gad kabd-ah sa-tuxruz } \quad \text { sala l-mare } \\
& \text { PART liver-3sGm go out.ra-IMPERF3sGF } \\
& \text { 'He was going to die (of love) for this woman.' }
\end{aligned}
$$

Before a verb in the imperative, gad expresses softened orders

$$
\begin{aligned}
& \text { gad gull la-nā rann-ak tāsib } \\
& \text { PART Say.IMP.SGM DAT-1PL CONJ -2SGM tire.PTCP.SGM } \\
& \text { 'You should have told us you are ill.' }
\end{aligned}
$$

Inversely, examples (126-127) are difficult to analyze. According to comments from my consultants, both sentences convey the "possible" notion. But this needs further study, as on the one hand, the meaning of the construction kān. IMPERF + PERF (jukūn $3 \bar{a})$, as seen above, anchors the sentence in the 'probable' domain (1.4. ex. 48), and, on the other hand, the construction with gad, as commented upon by my consultants, gives the particle a value that no longer corresponds to what was determined above (120-125).

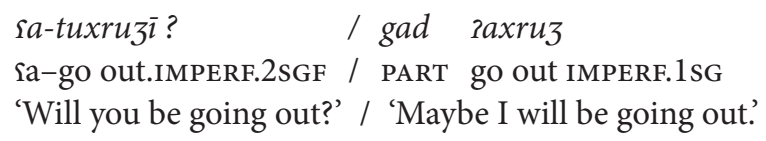

$$
\begin{array}{ll}
\text { gad jukūn } & 3 \bar{a} \\
\text { PART EXPT IMPERF.3SGM } & \text { come.PERF3SGM } \\
\text { 'Maybe he came.' } &
\end{array}
$$

Based on the data I have and until further research is carried out on the subject, one notes that gad precedes a motion verb ('come', 'go out') in both (126) and (127). Is there 
a link between the value attributed to gad in these constructions and this semantic category of verbs? More generally speaking, I wonder about the link between 'possible' and 'probable': are these two notions specifically marked in the Șañānī dialect?

\section{Conclusion}

The current configuration of the basic verbal system in the eastern and Yemeni dialects is presented in the table below. We have included a row which does not belong to the syntactic distribution of the perfective and imperfective paradigms, whether "bare" or prefixed, since it serves to express concomitance. However, specific marking for a relation of concomitance is one of the typological characteristics of the Arabic dialects: it embodies a specific type of change within the basic verbal system of Arabic dialect varieties. It would thus appear that among the varieties under study, only the eastern dialects specifically mark concomitance, using the particle sam. In the Yemeni dialects, it is the context which may express that a process has the aspect-tense characteristics of being concomitant with the speech event or with another process. Thus in the Șan ${ }^{\varsigma} \bar{n} \overline{1}$ dialect, the aspect particle $\varsigma^{a} d$ expresses continuation of an already ongoing process (2.2.1).

Table 1. Basic verbal system of eastern and Yemeni dialects

\begin{tabular}{|c|c|c|c|c|c|}
\hline Uses and meanings & IMPERF & b-IMPERF & Sam+b-IMPERF & PERF & РTCP \\
\hline Dependent constructions & SYA-ZYA-EA & & & SYA-ZYA-EA & \\
\hline $\begin{array}{l}\text { Modals: optative, jussive, } \\
\text { exhortative. Performative }\end{array}$ & SYA-ZYA-EA & & & SYA-ZYA-EA & $\mathrm{EA}$ \\
\hline $\begin{array}{l}\text { Conditionals (apodosis } \\
\text { and/or protasis), } \\
\text { procedural descriptions, } \\
\text { definitions, general truths }\end{array}$ & SYA-ZYA-EA & EA & & SYA-ZYA-EA & \\
\hline Habitual & ZYA & SYA & & & \\
\hline Concomitant & ZYA-SYA & & EA & & SYA-ZYA-EA \\
\hline
\end{tabular}

In this study, we broached separately the issue of the temporal auxiliary kān 'be' (1.4). This is because this auxiliary differs from aspectual auxiliaries, both in scope and in combinatory possibilities. kān has scope over the entire sentence, and provides temporal anchoring; aspectual auxiliaries have scope only over modified verbs. Moreover, temporal kān enters into more grammatical and syntactic combinations with the verbal predicate: alignment or crossing of $\mathrm{v}_{1}$ and $\mathrm{v}_{2}$ conjugations; the possibility of inserting a lexical subject between $\mathrm{v}_{1}$ and $\mathrm{v}_{2}$. Aspectual auxiliaries are subject to semantic (lexical) and syntactic constraints (2.1). 
Moreover, the present work shows that the participial form plays a role in encoding various aspectual meanings. Indeed, the participial form is in complementary distribution both with the perfective and the imperfective, not only to express concomitance with so-called 'middle' verbs (1.3) but also in performative sentences (1.2), with ingressive aspect (2.1.2.2) and continuative aspect (2.1.3., 2.2.1). This complementarity is in keeping with the possible semantic combinations between the auxiliary and aspectual particles. But it also depends on the viewpoint expressed by the speakernarrator, as we noted on the subject of the ingressive.

To understand the ingressive aspect meaning encoded by qām 'get up' (2.1.2.1), we compared two possible constructions, the first using juxtaposition, the second coordination. This comparison highlights the 'suddenness' characteristic of the ingressive aspect: the juxtaposition of events introduced by the auxiliary qām contributes to blurring the frontier between two events, presenting them as simultaneous; coordination serves to render a sequential representation, where events each follow in turn.

Moreover, expressing the ingressive by the auxiliary zaza (2.1.2.2) raises another issue in connection with the speaker-narrator viewpoint. As we saw above, the eastern dialects have two other auxiliaries, in addition to get up, to express the ingressive, $r \bar{a} \hbar$ 'go' and raza 'come'. These auxiliaries do not combine with the same elements, as raza is compatible both with finite verbs and participial forms. Depending on the perspective adopted by the speaker, the state of affairs is represented either dynamically or statically. In (71), the construction raza tasan- $u$ 'He ran it through' (AUX+stab.PERF) encodes a dynamic process; in (72) the construction with the participial form, rzza mlarzah (AUX + PTCP) '[there he was] flat out', expresses entry into a state.

Moreover, the ingressive inchoative distinction can be ambivalent in some semantic contexts, even when the two aspectual notions each have their own specific markers. This is the result, as we saw in (2.1.2.3), of interaction between grammatical and lexical aspect. What is shared by the ingressive and inchoative is that they mark the beginning of a process (represented by a closed left interval). However, with the inchoative, the process is represented as covering a certain temporal interval with the initial instant being marked (represented by an open right boundary), whereas with the ingressive, what is expressed is the sudden advent of an event (represented by a closed interval).

\section{References}

Austin, John Langshaw. 1970. Quand dire c'est faire. Paris: Seuil.

Benveniste, Émile. 1966. Problèmes de linguistique générale, Vol. 1. Paris: Gallimard.

Behnstedt, Peter. 1987. Die Dialeckte der Gegend von Șa dah (Nord-Jemen). Wiesbaden: Harrassovitz. 
Bussmann, Hadumod. 1996. Dictionary of Language and Linguistics. London: Routledge.

Cohen, David. 1989. Laspect verbal. Paris: Presses universitaires de France.

Cohen, Marcel. 1924. Le système verbal sémitique et l'expression du temps. Paris: Ernest Leroux.

Culioli, Antoine. 1990. Pour une linguistique de l'énonciation. Paris: Ophrys.

Desclés, Jean-Pierre. 1989. State, event, process, and topology. General Linguistics 29(3): 159-200.

Féghali, Michel. 1928. Syntaxe des parlers arabes actuels du Liban. Paris: Paul Geuthner.

Kouloughli, Djamel Eddine. 2007. Le résumé de la grammaire arabe par Zamakšarī, Paris: ENS éditions.

Naïm-Sanbar, Samia. 1993. Les performatifs explicites et le "présent" d’allocution. Paroles yéménites. Langage et société 66: 41-61.

Naïm, Samia. 2009. L’arabe yéménite de Sanaa. Leuven: Peeters. DOI: 10.3406/lsoc.1993.2633

Naïm, Samia. 2011. La grammaticalisation de quelques verbes de mouvement et de posture dans des dialectes arabes. Workshop: Grammaticalisation in Semitic. Salford: The University of Salford.

Recanati, François. 1981. Les énoncés performatifs. Paris: Minuit.

Rossi, Ettore. 1938. Appunti di dialettologia del Yemen. RSO 17: 230-472.

Rossi, Ettore. 1939. Larabo parlato a Sanầ. Roma: Istituto per L'oriente.

Searle, John 1976, A classification of illocutionary acts. Language in Society 5: 1-23. DOI: $10.1017 /$ S0047404500006837

Vanhove, Martine. 1996. Les particules qad et $r a^{\complement}$ dans un dialecte arabe de la région de Yāfi ${ }^{\mathrm{S}}$ (Yémen). In Proceedings of the 2nd International Conference of AIDA, 243-252.

Watson, Janet. 1993. A syntax of San'ani Arabic. Semitica Viva 13. Wiesbaden: Harrassowitz.

Watson, Janet. 2012. The Structure of Mehri. Wiesbaden: Harrassowitz.

Werbeck, Wolfgang. 2001. Laut- und Formenlehre des NordJemenitisch-Arabischen Dialekts von Manāha. Münster: Arabica Rhema.

Woidich, Manfred. 2006. Das Kairenisch-Arabische. Wiesbaden: Harrassowitz. 